\title{
Effects of ractopamine hydrochloride and immunological castration in pigs. Part 2: belly quality characteristics and fatty acid composition
}

\author{
Letícia Cristina COSTA E SILVA ${ }^{1 \star}$, Roger Darros BARBOSA ${ }^{1}$, Expedito Tadeu Facco SILVEIRA ${ }^{2 \dagger}$
}

\begin{abstract}
The effects of immunocastration and ractopamine in the diet on the belly quality were investigated from two crossbred pigs under different conditions of production, diet, management, and slaughter arranged in factorial design using two levels of addition of ractopamine in the diet, 0 and $7.5 \mathrm{ppm}$, and three genders (gilts, immunocastrated and barrows). The quality of bellies were analyzed for chemical composition, $\mathrm{pH}$, meat and fat color, backfat thickness and fatty acid profile of the fat. The addition of ractopamine showed no significant influence on $\mathrm{pH}$, color and chemical composition in two crossbred pigs. The immunocastrated had thicker belly backfat compared to the bellies of the gilts. The contents of fatty acids polyunsaturated, linoleic, linoleic, arachidonic, total omega 3 and omega 6 were higher for immunocastrated pigs, as well as presenting values greater than 0.4 for the PUFA:SFA ratio, thus, providing bellies with better nutritional quality. The bellies of the gilts and immunocastrated pigs had higher concentrations of iodine value, indicative of higher unsaturated fat content. The results indicated that the addition of ractopamine and immunocastration had little influence on the quality of bellies as well as in their fatty acid profiles, suggesting the continuity of implementation of these techniques.
\end{abstract}

Keywords: ractopamine; immunocastration; belly quality; fatty acids.

Practical Application: Belly and bacon processing pork industry linked to male immunocastration and Ractopamine fed pigs.

\section{Introduction}

Ractopamine is a beta-adrenergic additive used in the nutrition of pigs due to its ability to increase yield and deposition of muscle tissue in the carcass. It has the similar structure of the catecholamines, epinephrine and norepinephrine, which acts by changing the animal metabolism. Thus, the reduction in lipid synthesis, accompanied by increase in protein and muscle development, improve the performance (feed conversion) and hence the carcass characteristics of swine (Warriss, 2010).

Surgical castration, or physical castration, does not meet the animal welfare demands, but it is effective in preventing boar taint, but there are other disadvantages such as reducing growth performance and increasing fat deposition (Dunshea et al., 2001; Rikard-Bell et al., 2009). Immunocastration emerged as an alternative to avoid surgical castration and can be considered focused on animal welfare to be a virtually painless technique to animals, with quality and efficiency gains (Dunshea et al., 2005).

The cooled belly is a major component of swine carcass and contributes substantially to the total value of pig carcasses (Cantarelli et al., 2008). Also, according to this author, in general, consumers prefer meat with less fat, regardless of its presentation form. Thus, the lipids deposited in smaller amounts in the carcass can turn the cut into a more attractive one, as well as providing longer product shelf life, due to lower lipid oxidation (Fernandes, 1995). Accordingly, the present study aimed to assess the effect of the addition of ractopamine in the pig diet with a range of genders, immunocastrated, physically castrated barrows and gilts from two genetic lines under different conditions of production, diet, management and slaughter, on the bellies quality characteristics, expressed in terms of $\mathrm{pH}$, meat and fat color and backfat thickness, chemical composition and fatty acid profile.

\section{Material e methods}

\subsection{Animals and treatments}

All procedures involving live animals in this study were approved by the Committee of Ethics in Animal Experimentation in Campinas, Brazil, according to Brazilian federal standards (Brasil, 2000).

The study was based on 310 animals (95 gilts, 107 immunocastrated and 108 barrows) in the termination phase, with an average weight between $108-129 \mathrm{~kg}$, separated by gender, from two genetic lines "Topigs, Large White $\mathrm{x}$ Landrace x Duroc" (202) from the Água Branca farm, located in Fartura, and "Agroceres PIC, Duroc x Landrace x Pietran" (108) from Bressiani farm, located in Capivari, both in the state of Sao Paulo. 
Pigs were housed on solid-concrete floor pens and provided with ad libitum access to feed and water. Part of the entire male pigs, were randomly selected to be physically castrated between the third and the fifth day after birth, and the other part designated to be immunocastrated received the first dose of vaccine (Vivax ${ }^{\circledR}$, Pfizer Animal Health) eight weeks before slaughter, and the second dose four weeks from the date scheduled for slaughter. Twenty days prior to slaughter, the animals were relocated to receive two different levels of ractopamine in the diet (0 and 7.5 ppm; Ractosuin ${ }^{\circledR}$, Ourofino Agribusiness) in conventional diet, based on corn and soybeans, formulated with $16 \%$ of protein and $0.91 \%$ of lysine.

\subsection{Slaughter and carcass cut-out analysis}

The animals were slaughtered according to the Regulation of the Industrial and Sanitary Inspection of Animal Products (Brasil, 1997). After slaughter, using the Hennessy Grading Probe $^{\circledR}$ (Hennessy Grading Systems GP4/BP4, DIDAI), hot half carcasses were evaluated by weight ranging from 46 to $51 \mathrm{~kg}$ and fat thickness and muscle of 15 to $20 \mathrm{~mm}$ and 64 to $68 \mathrm{~mm}$ respectively. Five bellies from each treatment for the two genetic lines studied were transported to the Institute of Food Technology, Campinas, State of São Paulo, Brazil and analyzed of the quality characteristics, in terms of chemical composition, $\mathrm{pH}$, meat and fat color, thickness of backfat and fatty acids profile from fat.

\subsection{Analyzes of $\mathrm{pH}$ and objective color}

Objective color and $\mathrm{pH}$ of the bellies were measured immediately after thawing at $4 \pm 1{ }^{\circ} \mathrm{C}$ for 24 hours. The color of meat and of fat was obtained from four measurements at predetermined specific points on the surface. The evaluation of color, by the CIELab System, was carried out using a Minolta colorimeter (CR-400 Model, Konica Minolta Sensing, NJ, USA) with a D65 illuminant and $10^{\circ}$ angle with white calibration standard, evaluating the color parameters lightness $\mathrm{L}^{\star}(0=$ black; $100=$ white $)$, and $\mathrm{a}^{\star}$ and $\mathrm{b}^{\star}$ coordinates $\left(\mathrm{a}^{\star}:+=\right.$ red, $-=$ green; $\mathrm{b}^{\star}:+=$ yellow, $-=$ blue). The $\mathrm{pH}$ was determined using a direct puncture $\mathrm{pH}$ meter from Hanna Instruments (H199163 model, Woonsocket, RI, USA) calibrated at $\mathrm{pH} 4.0$ and 7.0, with the values obtained from four measurements of three belly slices of each treatment.

\subsection{Analysis of chemical composition}

The total protein content was analyzed by the Kjeldahl method, using the conversion factor of 6.25 (Association of Official Analytical Chemists, 2005). The extraction of fat was carried out in a Soxhlet apparatus using petroleum ether. The moisture was determined by the drying method at $105^{\circ} \mathrm{C}$ to constant weight and the ash content was determined by incinerating oven method at $550{ }^{\circ} \mathrm{C}$ (Association of Official Analytical Chemists, 2005).

\subsection{Analysis of backfat thickness}

The determination of the backfat thickness was performed by a commercial methodology suggested by Elanco Company of Brazil. The thickness of backfat was obtained using a caliper,

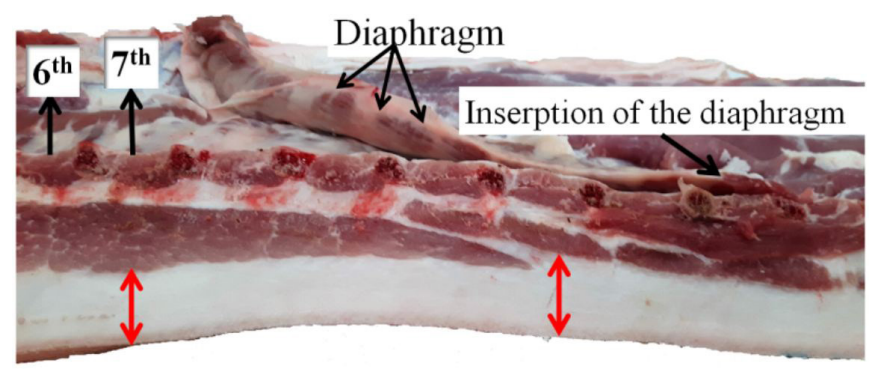

Figure 1. Location of points for determination of the backfat thickness, identified as the two red double arrows. Source: Leticia C. C. Silva.

measuring at two different points from 4 bellies of each treatment; the first point of measurement by the 7th intercostal space and the second measuring point in the intercostal space anterior to the diaphragm insertion (Figure 1).

\subsection{Analysis of fatty acid profile}

Samples of the fat (subcutaneous adipose tissue) from bellies containing three layers of fat formed during the animal growth (between $6^{\text {th }}$ and $7^{\text {th }}$ ribs; Figure 1) were carefully removed and homogenized for fatty acids analysis according to Hartman \& Lago (1973). The identification of the peaks was verified by comparison with the retention time of standard methyl esters of fatty acids. The area of each peak of fatty acids was represented as percentage of the total area. The iodine value (IV) of the fatty acids was analyzed using Equation 1 (American Oil Chemists Society, 1998).

$$
\begin{aligned}
& I V=(0.95)(C 16: 1)+(0.86)(C 18: 1 n 9)+(1.732)(C 18: 2 n 6)+ \\
& (2.616)(C 18: 3 n 3)+(9.785)(C 20: 1)+(0.785)(C 22: 1)
\end{aligned}
$$

\subsection{Statistical analyzes}

The $2 \times 3$ factorial design with randomized block design was used to analyze the belly quality results $(\mathrm{pH}$, meat color, fat color, chemical composition, backfat thickness and fatty acids profile from fat). The statistical model included the main effects of adding two levels of ractopamine in the $\operatorname{diet}(0 \mathrm{vs} 7.5 \mathrm{ppm})$ and three genders (barrows vs immunocastrated vs gilts), in addition to the interaction between the main effects (ractopamine and gender), in a factorial arrangement in blocks of the two genetic lines (Agua Branca and Bressiani) under different conditions of production, diet, management and slaughter. In case of significant interactions $(P<0.05)$ using ANOVA analysis, we proceeded to the Tukey's test for multiple comparison of means. The statistical analyzes of data were performed using Statistica 7 (StatSoft, 2004).

\section{Results and discussion}

The results for $\mathrm{pH}$ showed no significant difference $(P>0.05)$ for the effects of gender and addition of ractopamine in the diet, as shown on Table 1. These results favor the addition of ractopamine in pig diets, considering that the use of $\beta$ agonists could cause a high level of stress to the animal and develop PSE meat (Pale, Soft and Exudative) or stimulate glycolysis, thereby promoting ante-mortem muscular glycogen consumption, 
resulting in accumulation of lactic acid in the carcass after slaughter (Boler et al., 2010), which would be detected by a pH decrease, not observed in the present study.

The addition of ractopamine in the diet also showed no significant difference $(P>0.05)$ for all objective color parameters $\left(\mathrm{L}^{\star}, \mathrm{a}^{*}\right.$ and $\left.\mathrm{b}^{\star}\right)$ analyzed as shown on Table 1 . Similar results to this study were obtained by Apple et al. (2007), who found no significant difference in meat color and fat color in the bellies of pigs receiving 0 and $10 \mathrm{ppm}$ of ractopamine in the diet. Leick et al. (2010), analyzing bellies from pigs that received 0 and $5 \mathrm{ppm}$ of ractopamine, did not observe any changes in the fat color parameters $L^{*}, a^{*}$ and $b$ * with the addition of ractopamine; similar results were also found by Carr et al. (2005).
For the color of belly meat as influenced by gender (Table 1), it was observed that bellies of physically castrated and immunocastrated pigs showed lower values for the meat color parameter $\mathrm{a}^{*}$ compared to the belly from gilts, a fact which, according to Carr et al. (2005), indicates low levels of oxymyoglobin present in the bellies, possibly due to the dilution effect caused by hypertrophy of muscle fibers. The color of the belly fat from physically castrated animals that did not receive ractopamine in the diet showed the lowest $\mathrm{L}^{*}$ value, therefore darker compared to gilts; however, the belly fat color of immunocastrated animals did not differ from barrows and gilts).

Tables 2 and 3 present the results for the chemical composition of the bellies. Gender showed significant differences $(P<0.05)$

Table 1. Results of physicochemical quality of bellies as a function of gender and ractopamine level.

\begin{tabular}{|c|c|c|c|c|c|c|c|c|c|}
\hline & & & \multirow{2}{*}{$\mathrm{pH}$} & \multicolumn{3}{|c|}{ Meat Color } & \multicolumn{3}{|c|}{ Fat Color } \\
\hline & & & & $\mathrm{L}^{*}$ & $\mathrm{a}^{*}$ & $\mathrm{~b}^{*}$ & $\mathrm{~L}^{*}$ & $a^{*}$ & $b^{*}$ \\
\hline \multirow{5}{*}{ Gender } & Gilt & & 5.905 & 40.23 & $10.86^{\mathrm{a}}$ & 1.013 & 71.26 & 4.429 & 5.847 \\
\hline & Barrow & & 5.903 & 42.28 & $9.213^{\mathrm{b}}$ & 2.582 & 69.85 & 4.761 & 5.959 \\
\hline & Immunocastratec & & 5.908 & 42.57 & $8.596^{\mathrm{b}}$ & 1.589 & 70.13 & 4.248 & 6.000 \\
\hline & & SEM & 0.017 & 1.230 & 0.520 & 0.541 & 0.585 & 0.315 & 0.208 \\
\hline & & $P$-value & 0.979 & 0.064 & 0.007 & 0.153 & 0.119 & 0.463 & 0.849 \\
\hline \multirow{5}{*}{$\begin{array}{l}\text { Ractopamine } \\
\text { (ppm) }\end{array}$} & 0.0 & & 5.897 & 41.93 & 9.951 & 2.243 & 70.39 & 4.482 & 5.855 \\
\hline & 7.5 & & 5.913 & 41.47 & 9.200 & 1.260 & 70.38 & 4.480 & 6.014 \\
\hline & & SEM & 0.013 & 1.011 & 0.446 & 0.446 & 0.494 & 0.256 & 0.168 \\
\hline & & $P$-value & 0.465 & 0.979 & 0.134 & 0.087 & 1.000 & 0.897 & 0.491 \\
\hline & & CV (\%) & 1.96 & 15.6 & 30.2 & 16.8 & 4.12 & 33.8 & 16.8 \\
\hline
\end{tabular}

${ }^{\text {ab }}$ Means within the same column with different superscripts differ significantly at 5\% level of significance for gender and ractopamine level. SEM: Standard error of the mean for all treatments. CV: Coefficient of variation. $\left(\mathrm{L}^{\star}\right)$ Lightness; $\left(\mathrm{a}^{*}\right)$ Redness; $\left(\mathrm{b}^{*}\right)$ Yellowness.

Table 2. Proteins, lipids, moisture, ash and backfat thickness for bellies as a function of gender and ractopamine level.

\begin{tabular}{|c|c|c|c|c|c|c|c|}
\hline & & Proteins (\%) & Lipids (\%) & Moisture (\%) & $\begin{array}{l}\text { Ash } \\
(\%)\end{array}$ & $\begin{array}{c}\text { Carbohydrates } \\
(\%)\end{array}$ & $\begin{array}{c}\text { Backfat } \\
\text { thickness }(\mathrm{cm})\end{array}$ \\
\hline \multirow{5}{*}{ Gender } & Gilt & $13.98^{\mathrm{a}}$ & $30.01^{\mathrm{ab}}$ & 52.52 & $0.793^{\mathrm{a}}$ & 2.697 & $2.262^{\mathrm{b}}$ \\
\hline & Barrow & $12.07^{\mathrm{b}}$ & $33.40^{\mathrm{a}}$ & 52.60 & $0.719^{\mathrm{ab}}$ & 1.203 & $2.320^{\mathrm{ab}}$ \\
\hline & Immunocastrated & $12.79^{\mathrm{ab}}$ & $26.57^{\mathrm{b}}$ & 55.71 & $0.705^{\mathrm{b}}$ & 4.226 & $2.652^{\mathrm{a}}$ \\
\hline & SEM & 0.537 & 1.344 & 1.604 & 0.019 & 1.057 & 0.979 \\
\hline & $P$-value & 0.006 & 0.004 & 0.238 & 0.025 & 0.120 & 0.015 \\
\hline \multirow{5}{*}{$\begin{array}{l}\text { Ractopamine } \\
\text { (ppm) }\end{array}$} & 0.0 & 12.66 & 28.98 & 53.89 & 0.731 & 3.739 & 2.460 \\
\hline & 7.5 & 13.24 & 31.01 & 53.32 & 0.747 & 1.678 & 2.362 \\
\hline & SEM & 0.469 & 1.362 & 1.459 & 0.020 & 0.934 & 0.883 \\
\hline & $P$-value & 0.188 & 0.175 & 0.739 & 0.523 & 0.084 & 0.388 \\
\hline & CV (\%) & 12.9 & 15.8 & 9.35 & 9.38 & 14.0 & 17.9 \\
\hline
\end{tabular}

${ }^{\text {ab }}$ Means within the same column with different superscripts differ significantly at 5\% level of significance for gender and ractopamine level. SEM: Standard error of the mean for all treatments; CV: Coefficient of variation.

Table 3. Protein and carbohydrate contents and color of fat as affected by the interaction between gender and ractopamine level.

\begin{tabular}{|c|c|c|c|c|c|c|}
\hline & \multirow{2}{*}{$\begin{array}{c}\text { Ractopamine } \\
(\mathrm{ppm})\end{array}$} & \multicolumn{3}{|c|}{ Gender } & \multirow{2}{*}{ SEM } & \multirow{2}{*}{$P$-value } \\
\hline & & Gilt & Barrow & Immunocastrated & & \\
\hline \multirow{2}{*}{ Proteins (\%) } & 0.0 & $14.94^{\mathrm{ax}}$ & $10.82^{\text {by }}$ & $12.21^{\mathrm{bx}}$ & 0.533 & \multirow{2}{*}{0.002} \\
\hline & 7.5 & $13.01^{\mathrm{ax}}$ & $13.33^{\mathrm{ax}}$ & $13.37^{\mathrm{ax}}$ & 0.615 & \\
\hline \multirow{2}{*}{ Carbohydrates (\%) } & 0.0 & $2.963^{\mathrm{ax}}$ & $0.396^{\mathrm{bx}}$ & $7.869^{\mathrm{ax}}$ & 1.555 & \multirow{2}{*}{0.013} \\
\hline & 7.5 & $2.431^{\mathrm{ax}}$ & $2.020^{\mathrm{ax}}$ & $0.582^{\text {ay }}$ & 0.570 & \\
\hline \multirow{2}{*}{$\begin{array}{l}\text { Fat Color } \\
\left(\mathrm{L}^{*} \text { value }\right)\end{array}$} & 0.0 & $71.82^{\mathrm{ax}}$ & $68.82^{b x}$ & $70.78^{\mathrm{abx}}$ & 0.917 & \multirow{2}{*}{0.022} \\
\hline & 7.5 & $70.80^{\mathrm{ax}}$ & $70.87^{\mathrm{ax}}$ & $69.47^{\mathrm{ax}}$ & 0.679 & \\
\hline
\end{tabular}

${ }^{\text {ab }}$ Means within the same row with different superscripts differ significantly at $5 \%$ levels of significance for gender. ${ }^{x y}$ Means within the same column with different superscripts differ significantly at $5 \%$ levels of significance for ractopamine level. SEM: Standard error of the mean of all treatments. 
for total proteins and total lipids contents. Table 2 shows the comparison of means among genders for the contents of proteins, lipids, moisture and ashes. The bellies from immunocastrated pigs had lower lipid content and higher protein content than castrated barrows, in this case as result of the metabolism of increasing fat deposition due to (Rikard-Bell et al., 2009), an important positive result of the immunological castration technique towards obtaining leaner meats. Barrows which had received ractopamine in the diet had higher protein contents compared to animals that did not receive ractopamine, although ractopamine fed animals had similar protein contents regardless of gender (Table 3), which is also considered a positive combined effect of the immunocastration and ractopamine techniques, towards better swine belly characteristics.

Scramlin et al. (2008) found higher moisture content and lower content of lipids for gilts compared with barrows with different levels of ractopamine $(0,5$ and $7.4 \mathrm{ppm})$ in the pigs diet. In the same research work, gilts have also shown higher amount of lean meat on bellies, by the analysis of the area of belly slices using Adobe Photoshop, with the result also reflected on the chemical composition.

The analysis for the thickness of belly backfat showed significant differences $(P<0.05)$ only by gender, as shown on Table 2. The bellies of the gilts showed lower backfat thickness compared to the bellies of immunocastrated pigs, even though immuncastrated pigs showed lower lipid content of their bellies than castrated ones. However, Correa et al. (2008) found thinner bellies of gilts of the genetic Duroc x (Landrace x Yorkshire) compared to the bellies of barrow animals. For the present study, no differences were found between the two genetic from different commercial farms studied, possibly considering that the Duroc $x$ Landrace crossbred being present in both genetic lines investigated.

Ferreira et al. (2011) reported that there was a reduction in the thickness of gilt and barrow belly backfat with the addition of up to $15 \mathrm{ppm}$ of ractopamine in the diet. Several authors reported decreased deposition of fat in the carcass of swine fed ractopamine (Mimbs et al., 2005); however, there is still no consensus on whether this decline is due to the reduction of lipogenesis or increased lipolysis. Yet, no effect was found in the present study in the thickness of the belly backfat due to the addition of ractopamine.

The results of the fatty acid profile of the bellies as influenced by gender, ractopamine levels, interaction (gender and ractopamine) for the animals from the two farms studied are presented on Tables 4 and 5.

The bellies from immunocastrated pigs showed higher levels of polyunsaturated fatty acids (total PUFA), linoleic acid (C18:2n6), linolenic acid (C18:3n3), arachidonic acid (C20:4n6), omega-3 (total n-3) and omega-6 (total n-6) and smaller palmitic acid content (C16:0), compared to the bellies of castrated animals (Table 4). According to Furman et al. (2010), high content of unsaturated fatty acids occurs in parallel with lower content of total lipids, because leaner pigs synthesize small amounts of fatty acids in the tissue causing an increase in the proportion of unsaturated fatty acids.

Bellies from gilt pigs showed lower concentration of saturated fatty acids (total SFA), myristic acid (C14:0) and palmitic acid (C16:0) compared to the bellies of barrow pigs (Table 4).

Table 4. Fatty acid profile as a function of gender and ractopamine level.

\begin{tabular}{|c|c|c|c|c|c|c|c|c|c|c|}
\hline \multirow{2}{*}{ Fatty acid ${ }^{w}$} & \multicolumn{3}{|c|}{ Gender } & \multirow{2}{*}{ SEM } & \multirow{2}{*}{$P$-value } & \multicolumn{2}{|c|}{ Ractopamine (ppm) } & \multirow{2}{*}{ SEM } & \multirow{2}{*}{$P$-value } & \multirow{2}{*}{$\mathrm{CV}(\%)$} \\
\hline & Gilt & Barrow & Immunocastrated & & & 0.0 & 7.5 & & & \\
\hline SFA & $35.87^{b}$ & $37.57^{\mathrm{a}}$ & $36.45^{\mathrm{ab}}$ & 2.012 & 0.009 & $36.61^{\mathrm{a}}$ & $36.66^{\mathrm{a}}$ & 0.435 & 0.905 & 5.71 \\
\hline Myristic (C14:0) & $1.301^{\mathrm{b}}$ & $1.453^{\mathrm{a}}$ & $1.400^{\mathrm{ab}}$ & 0.122 & 0.005 & $1.358^{\mathrm{a}}$ & $1.412^{\mathrm{a}}$ & 0.029 & 0.158 & 10.3 \\
\hline Palmitic (C16:0) & $23.18^{\mathrm{b}}$ & $24.43^{\mathrm{a}}$ & $23.33^{\mathrm{b}}$ & 1.083 & 0.001 & $23.50^{\mathrm{a}}$ & $23.82^{\mathrm{a}}$ & 0.253 & 0.329 & 5.17 \\
\hline Stearic (C18:0) & $11.23^{\mathrm{a}}$ & $11.50^{\mathrm{a}}$ & $11.52^{\mathrm{a}}$ & 0.304 & 0.705 & $11.59^{\mathrm{a}}$ & $11.24^{\mathrm{a}}$ & 0.245 & 0.161 & 10.5 \\
\hline Arachidic (C20:0) & $0.167^{\mathrm{a}}$ & $0.177^{\mathrm{a}}$ & $0.171^{\mathrm{a}}$ & 0.006 & 0.428 & $0.172^{\mathrm{a}}$ & $0.171^{\mathrm{a}}$ & 0.005 & 0.951 & 13.7 \\
\hline MUFA & $46.37^{\mathrm{a}}$ & $45.25^{\mathrm{ab}}$ & $44.66^{\mathrm{b}}$ & 1.452 & 0.006 & $45.30^{\mathrm{a}}$ & $45.60^{\mathrm{a}}$ & 0.342 & 0.467 & 3.62 \\
\hline Palmitoleic (C:16:1c) & $2.217^{\mathrm{a}}$ & $2.332^{\mathrm{a}}$ & $2.227^{\mathrm{a}}$ & 0.063 & 0.407 & $2.225^{\mathrm{a}}$ & $2.295^{\mathrm{a}}$ & 0.054 & 0.382 & 11.6 \\
\hline Oleic (C18:1n9) & $40.73^{\mathrm{a}}$ & $39.57^{\mathrm{b}}$ & $39.13^{\mathrm{b}}$ & 1.233 & 0.003 & $39.73^{\mathrm{a}}$ & $39.92^{\mathrm{a}}$ & 0.298 & 0.583 & 3.60 \\
\hline Vaccenic (C18:1 trans11) & $2.485^{\mathrm{a}}$ & $2.456^{\mathrm{a}}$ & $2.416^{\mathrm{a}}$ & 0.039 & 0.479 & $2.443^{\mathrm{a}}$ & $2.463^{\mathrm{a}}$ & 0.034 & 0.664 & 6.69 \\
\hline Gadoleic (C20:1w9) & $0.704^{\mathrm{a}}$ & $0.694^{\mathrm{a}}$ & $0.705^{\mathrm{a}}$ & 0.023 & 0.843 & $0.697^{\mathrm{a}}$ & $0.705^{\mathrm{a}}$ & 0.019 & 0.584 & 12.9 \\
\hline PUFA & $14.89^{\mathrm{ab}}$ & $14.08^{\mathrm{b}}$ & $15.66^{\mathrm{a}}$ & 1.717 & 0.001 & $14.96^{\mathrm{a}}$ & $14.76^{\mathrm{a}}$ & 0.375 & 0.736 & 12.1 \\
\hline Linoleic (C18:2n6) & $13.97^{\mathrm{ab}}$ & $13.24^{\mathrm{b}}$ & $14.68^{\mathrm{a}}$ & 1.637 & 0.001 & $14.04^{\mathrm{a}}$ & $13.86^{\mathrm{a}}$ & 0.356 & 0.777 & 12.3 \\
\hline Linolenic (C18:3n3) & $0.637^{\mathrm{b}}$ & $0.601^{\mathrm{b}}$ & $0.694^{\mathrm{a}}$ & 0.082 & 0.001 & $0.649^{\mathrm{a}}$ & $0.637^{\mathrm{a}}$ & 0.018 & 0.649 & 13.9 \\
\hline Arachidonic (C20:4n6) & $0.290^{\mathrm{a}}$ & $0.239^{\mathrm{b}}$ & $0.283^{\mathrm{a}}$ & 0.037 & 0.001 & $0.280^{\mathrm{a}}$ & $0.259^{\mathrm{b}}$ & 0.042 & 0.036 & 16.0 \\
\hline Other fatty acid & $2.867^{\mathrm{b}}$ & $3.095^{\mathrm{ab}}$ & $3.215^{\mathrm{a}}$ & 0.829 & 0.003 & $3.127^{\mathrm{a}}$ & $2.981^{\mathrm{a}}$ & 0.060 & 0.082 & 9.80 \\
\hline n-3 PUFA & $0.637^{\mathrm{b}}$ & $0.601^{\mathrm{b}}$ & $0.694^{\mathrm{a}}$ & 0.082 & 0.001 & $0.649^{\mathrm{a}}$ & $0.640^{\mathrm{a}}$ & 0.018 & 0.649 & 13.9 \\
\hline n-6 PUFA & $14.24^{\mathrm{ab}}$ & $13.48^{\mathrm{b}}$ & $14.97^{\mathrm{a}}$ & 1.632 & 0.001 & $14.30^{\mathrm{a}}$ & $14.12^{\mathrm{a}}$ & 0.356 & 0.769 & 12.1 \\
\hline Trans total & $0.232^{\mathrm{a}}$ & $0.191^{\mathrm{ab}}$ & $0.188^{\mathrm{b}}$ & 0.051 & 0.028 & $0.197^{\mathrm{a}}$ & $0.212^{\mathrm{a}}$ & 0.011 & 0.352 & 26.8 \\
\hline Iodine value & $63.55^{\mathrm{a}}$ & $61.30^{\mathrm{b}}$ & $63.57^{\mathrm{a}}$ & 2.968 & 0.001 & $62.84^{\mathrm{a}}$ & $62.74^{\mathrm{a}}$ & 0.643 & 0.899 & 4.93 \\
\hline
\end{tabular}

${ }^{\text {ab }}$ Means within the same row with different superscripts differ significantly at 5\% level of significance for gender and ractopamine level. SEM: Standard error of the mean of all treatments;

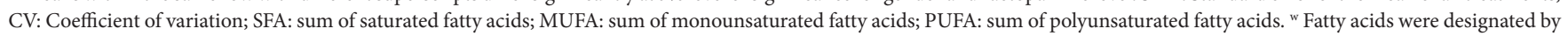
the number of carbon atoms followed by the number of double bonds. The position of the first double bond relative to the methyl (n) end of the molecule. 
Table 5. Total saturated fatty acids (SFA), Total monounsaturated fatty acids (MUFA) and Oleic (C18:1n9) acid content as affected by the interaction between gender and ractopamine level.

\begin{tabular}{|c|c|c|c|c|c|c|}
\hline \multirow{2}{*}{ Fatty acid ${ }^{w}$} & \multirow{2}{*}{$\begin{array}{l}\text { Ractopamine } \\
\text { (ppm) }\end{array}$} & \multicolumn{3}{|c|}{ Gender } & \multirow{2}{*}{ SEM } & \multirow{2}{*}{$P$-value } \\
\hline & & Gilt & Barrow & Immunocastrated & & \\
\hline \multirow{2}{*}{ SFA } & 0.0 & $35.71^{\text {ax }}$ & $36.98^{\mathrm{ax}}$ & $37.14^{\text {ax }}$ & 2.230 & \multirow{2}{*}{0.041} \\
\hline & 7.5 & $36.03^{\mathrm{abx}}$ & $38.15^{\mathrm{ax}}$ & $35.66^{\mathrm{bx}}$ & 1.712 & \\
\hline \multirow{2}{*}{ MUFA } & 0.0 & $46.16^{\text {ax }}$ & $45.99^{\mathrm{ax}}$ & $43.73^{\mathrm{bx}}$ & 1.072 & \multirow{2}{*}{0.005} \\
\hline & 7.5 & $46.57^{\text {ax }}$ & $44.51^{\mathrm{ax}}$ & $45.73^{\text {ax }}$ & 1.519 & \\
\hline \multirow{2}{*}{ Oleic $(\mathrm{C} 18: \ln 9)$} & 0.0 & $40.61^{\text {ax }}$ & $40.20^{\mathrm{ax}}$ & $38.37^{b x}$ & 0.775 & \multirow{2}{*}{0.007} \\
\hline & 7.5 & $40.85^{\mathrm{ax}}$ & $38.94^{\mathrm{bx}}$ & $39.99^{\mathrm{abx}}$ & 1.420 & \\
\hline
\end{tabular}

${ }^{\text {ab }}$ Means within the same row with different superscripts differ significantly at $5 \%$ levels of significance for gender; ${ }^{x y}$ Means within the same column with different superscripts differ significantly at $5 \%$ levels of significance for ractopamine level; ${ }^{\text {w }}$ Fatty acids were designated by the number of carbon atoms followed by the number of double bonds. SFA: sum of saturated fatty acids; MUFA: sum of monounsaturated fatty acids; SEM: Standard error of the mean of all treatments.

Houben \& Krol (1983) suggest that adipose tissue of good nutritional quality should contain less than 15\% of polyunsaturated fatty acids (total PUFA) and more than $12 \%$ linoleic acid (C18:2n-6). The bellies of immunocastrated animals in the present study showed $15.7 \%$ of polyunsaturated fatty acids (total PUFA) and $14.7 \%$ linoleic acid (C18:2n-6), values above the levels suggested by the authors.

The addition of ractopamine as main factor alone did not affect the fatty acid profile of the belly fat except for arachidonic acid (C20:4n6), which showed the highest level for pigs that did not receive ractopamine in the diet (Table 4). Shook (2006) suggests that in the ractopamine receiving phase, pigs would already have the outer fat layer formed and consequently this technology would have no major impact; the authors found no influence in the fatty acid profile due to the addition of $10 \mathrm{ppm}$ of ractopamine for gilts and barrows. However, in a research using large amounts of ractopamine in the diet (20 ppm), decreases were observed in lipogenic enzymes and in the so called synthesis "de novo" of fatty acids (Mills et al., 1990). The synthesis "de novo" of fatty acids occurs through a series of enzymatic reactions initiated by the presence of acetyl-coenzyme in the cytosol (Curi et al., 2001).

Other studies have shown that the genetic selection of swine animals has contributed a lot to a change in the degree of saturation of subcutaneous fat to less saturated forms (e.g. Scott et al., 1981; Cameron \& Enser, 1991; Correa et al., 2008). In the same line, the present study also showed that influence, since bellies of pigs from Bressiani farm (Agroceres PIC genetic) presented total polyunsaturated acid content (16.15\% total PUFA) and iodine value (65.18) greater than the bellies of the pigs from Água Branca farm (Topigs genetic), indicating a higher concentration of fat beneficial to human health from the first ones.

Immunocastrated animals fed with ractopamine in the diet (combined effect) had lower levels of saturated fatty acids (total SFA) compared to the castrated barrow animals, which is considered an important result, considered as an improvement for a healthy human diet. Gilts fed with ractopamine in the diet had higher content of oleic acid (C18:1n9) compared to the barrow pigs (Table 5).

For human food intake, the content of unsaturated fatty acids (total PUFA) omega-3 (n-3) and omega-6 (n-6) are important. However, high intake of omega- 6 can adversely impact human health, resulting in excessive production of eicosanoids, which eventually could lead to hypertension, inflammation and risk for developing diseases (Curi et al., 2001). The ratio between the total omega- $6(n-6)$ and the total omega- $3(n-3)$ in all groups of pigs investigated was higher than the recommended or generally accepted (4:1) for pork meat (Wood et al., 2008). The main source of fatty acids omega- 3 (n-3) found was the linolenic acid (C18:3n3), while the major fatty acids as sources of omega-6 (n-6) were linoleic acid (C18:2n6), and arachidonic acid (C20:4n6).

The ratio PUFA:SFA in the diet is used as limiting risk parameter for cardiovascular disease in humans. All values obtained for the ratio PUFA:SFA showed values close to the acceptable ( $\geq 0.4)$; except for the castrated animals $(0.37)$ and for pigs from the Água Branca farm (0.36), which showed values lower than the nutritionally recommended (Furman et al., 2010).

The iodine value showed significant influence $(P<0.05)$ due to gender (Table 4 ). The bellies of gilt and immunocastrated animals had higher iodine values compared to the bellies of barrow animals. The change in iodine value is mainly due to a decrease in the concentration of palmitic acid (C16:0), myristic acid (C14:0) and of the total saturated fatty acids (total SFA), which were observed in immunocastrated animals. The iodine value is a measure of the degree of unsaturation present in the fat and therefore can used as an indicator of fat firmness. The results obtained in the present study did not exceed the maximum of 70 for the iodine value, index usually accepted by the industry as standard and considered as a reference for the fat to be classified as high-quality (Lea et al., 1970). The content of unsaturated fatty acids in the pig bellies is a major concern for the swine industry, since very soft bellies may become difficult for bacon slicing and cause the separation of fat from meat during slicing, and eventually may increase oxidation rate (National Pork Production Council, 1999).

\section{Conclusion}

The addition of ractopamine did not influence the thickness of belly backfat, contrasting with the gender for the two genetic lines investigated from the different commercial farms which resulted in significant differences. The bellies of the gilt pigs had lower backfat thicknesses, result already expected since female pigs are lighter animals than barrow and immunocastrated males.

The $\mathrm{pH}$, meat color and fat color of the bellies were not affected by the addition of ractopamine, however, the two genetic 
lines from the different commercial farms had some effect on meat color and fat color, otherwise not expected.

The addition of $7.5 \mathrm{ppm}$ of ractopamine in the diet only decreased arachidonic acid content (C20:4n6). The content of total poly-unsaturated fatty acids (total PUFA), linoleic acid (C18:2n6), linolenic acid (C18:3n3), arachidonic acid (C20:4n6), omega-3 (total n-3) and omega-6 (total n-6) were higher for immunocastrated animals and less palmitic acid content (C16:0) as compared to the bellies from physically castrated barrow animals. The results suggest that the technique of immunocastration provides a fatty acid profile of good nutritional quality, indicated by the ratio PUFA:SFA greater than 0.4 . The results for immunocastrated pigs indicate that this technology can be used as an alternative for the substitution of surgical castration, which also contribute to a lower level of stress for male pigs.

\section{References}

Association of Official Analytical Chemists. (2005). Official methods of analysis of Association of Official Analytical Chemists (18th ed.). Arlington: AOAC.

American Oil Chemists Society. (1998). Recommended practice Cd 1c-85. In Official Methods and Recommended Practices of the AOCS (5th ed.). Champaign: AOCS.

Apple, J. K., Maxwell, C. V., Sawyer, J. T., Kutz, B. R., Rakes, L. K., Davis, M. E., Johnson, Z. B., Carr, S. N., \& Armstrong, T. A. (2007). Interactive effect of ractopamine and dietary fat source on quality characteristics of fresh pork bellies. Journal of Animal Science, 85(10), 2682-2690. PMid:17609473. http://dx.doi.org/10.2527/jas.2007-0174.

Boler, D. D., Holmer, S. F., Duncan, D. A., Carr, S. N., Ritter, M. J., Stites, C. R., Petry, D. B., Hinson, R. B., Allee, G. L., McKeith, F. K., \& Killefer, J. (2010). Fresh meat and further processing characteristics of ham muscles from finishing pigs fed ractopamine hydrochloride. Journal of Animal Science, 89(1), 210-220. PMid:20817858. http:// dx.doi.org/10.2527/jas.2010-3041.

Brasil. Ministério da Agricultura, Pecuária e Abastecimento. (1997). Regulamento da inspeção industrial e sanitária de produtos de origem animal. Diário Oficial [da] República Federativa do Brasil, p. 241.

Brasil. Ministério da Agricultura, Pecuária e Abastecimento. (2000, January 17). Regulamento técnico de métodos de insensibilização para o abate humanitário de animais de açougue. Instrução normativa n ${ }^{\circ}$ 3 de 17 de janeiro de 2000. Diário Oficial [da] República Federativa do Brasil.

Cameron, N. D., \& Enser, M. (1991). Fatty acid composition of lipid in longissimus dorsi muscle of Duroc and British Landrace pigs and its relationship with eating quality. Meat Science, 29(4), 295-307. PMid:22061434. http://dx.doi.org/10.1016/0309-1740(91)90009-F.

Cantarelli, V. S., Zangeronimo, M. G., Almeida, E. C., Wolp, R. C., Pereira, L. M., \& Fialho, E. T. (2008). Qualidade de cortes de suínos recebendo ractopamina na ração em diferentes programas alimentares. Acta Scientiarum Animal Science, 2, 165-171.

Carr, S. N., Ivers, D. J., Anderson, D. B., Jones, D. J., Mowrey, D. H., England, M. B., Killefer, J., Rincker, P. J., \& McKeith, F. K. (2005). The effects of ractopamine hydrochloride on lean carcass yields and pork quality characteristics. Journal of Animal Science, 83(12), 28862893. PMid:16282628. http://dx.doi.org/10.2527/2005.83122886x.

Correa, J. A., Garie'py, C., Marcoux, M., \& Faucitano, L. (2008). Effects of growth rate, sex and slaughter weight on fat characteristics of pork bellies. Meat Science, 80(2), 550-554. PMid:22063365. http:// dx.doi.org/10.1016/j.meatsci.2007.12.018.
Curi, R., Pompéia, C., Miyasaka, C. K., \& Procopio, J. (2001). Entendendo a gordura: os ácidos graxos. Barueri: Manole Ltda.

Dunshea, F. R., Colantoni, C., Howard, K., McCauley, I., Jackson, P., Long, K. A., Lopaticki, S., Nugent, E. A., Simons, J. A., Walker, J., \& Hennessy, D. P. (2001). Vaccination of boars with a GnRH vaccine (Improvac) eliminates boar taint and increases growth performance. Journal of Animal Science, 79(10), 2524-2535. PMid:11721830. http:// dx.doi.org/10.2527/2001.79102524x.

Dunshea, F. R., D’souza, D. N., Pethick, D. W., Harper, G. S., \& Warner, R. D. (2005). Effects of dietary factors and other metabolic modifiers on quality and nutritional value of meat. Meat Science, 71(1), 8-38. PMid:22064049. http://dx.doi.org/10.1016/j.meatsci.2005.05.001.

Fernandes, T. (1995). Utilização de beta-agonistas como estimuladores do crescimento em animais destinados à produção de carne. In Anais do Instituto de Protecção da Produção Agro-Alimentar. Utilização dos promotores de crescimento (beta-agonistas) em animais destinados à produção de carne (pp. 39-49), Lisboa, Portugal.

Ferreira, M. S. S., Sousa, R. V., Silva, V. O., Zangerônimo, M. G., \& Amaral, N. O. (2011). Cloridrato de ractopamina em dietas para suínos em terminação. Acta Scientiarum, Animal Sciences, 33(1), 25-32.

Furman, M., Malovrh, S., Levart, A., \& Kovac, M. (2010). Fatty acid composition of meat and adipose tissue from Krskopolje pigs and commercial fatteners in Slovenia. Archiv fur Tierzucht, 1, 73-84.

Hartman, L., \& Lago, R. C. A. (1973). Rapid preparation of fatty acid methyl esters from lipids. Laboratory Practice, 22(8), 475-481. PMid:4727126.

Houben, J. H., \& Krol, B. (1983). Pig fats and the manufacture and storage of meat products. In Proceedings of the Fat Quality in Lean Pigs, Workshop in EEC Programme (pp. 15-26), Brussels.

Lea, C. H., Swoboda, P. A. T., \& Gatherum, D. P. (1970). A chemical study of soft fat in crossbred pigs. Journal of Agricultural Science, Cambridge, 74(02), 1-11. http://dx.doi.org/10.1017/S0021859600022899.

Leick, C. M., Puls, C. L., Ellis, M., Killefer, J., Carr, T. R., Scramlin, S. M., England, M. B., Gaines, A. M., Wolter, B. F., Carr, S. N., \& McKeith, F. K. (2010). Effect of distillers dried grains with solubles and ractopamine (Paylean) on quality and shelf-life of fresh pork and bacon. Journal of Animal Science, 88(8), 2751-2766. PMid:20407070. http://dx.doi.org/10.2527/jas.2009-2472.

Mills, S. E., Liu, C. Y., Gu, Y., \& Schinckel, A. P. (1990). Effects of ractopamine on adipose tissue metabolism and insulin binding in finishing hogs. Interaction with genotype and slaughter weight. Domestic Animal Endocrinology, 7(2), 251-264. PMid:2196159. http://dx.doi.org/10.1016/0739-7240(90)90031-T.

Mimbs, K. J., Pringle, T. D., Azain, M. J., Meers, S. A., \& Armstrong, T. A. (2005). Effects of ractopamine on performance and composition of pigs phenotypically sorted into fat and lean groups. Journal of Animal Science, 83(6), 1361-1369. PMid:15890813. http://dx.doi. org/10.2527/2005.8361361x.

National Pork Production Council. (1999). Pork composition and quality assessment procedures. Des Moines: NPPC.

Rikard-Bell, C., Curtis, M. A., van Barneveld, R. J., Mullan, B. P., Edwards, A. C., Gannon, N. J., Henman, D. J., Hughes, P. E., \& Dunshea, F. R. (2009). Ractopamine hydrochloride improves growth performance and carcass composition in immunocastrated boars, entire boars, and gilts. Journal of Animal Science, 87(11), 3536-3543. PMid:19648492. http://dx.doi.org/10.2527/jas.2009-2002.

Scott, R. A., Cornelius, S. G., \& Mersmann, H. J. (1981). Fatty acid composition of adipose tissue from lean and obese swine. Journal of Animal Science, 53(4), 977-981. http://dx.doi.org/10.2527/ jas1981.534977x. 
Scramlin, S. M., Carr, S. N., Parks, C. W., Fernández-Dueñas, D. M., Leick, C. M., McKeith, F. K., \& Killefer, J. (2008). Effect of ractopamine level, gender, and duration of ractopamine on belly and bacon quality traits. Meat Science, 80(4), 1218-1221. PMid:22063860. http://dx.doi. org/10.1016/j.meatsci.2008.05.034.

Shook, J. N. (2006). The interaction of ractopamine hydrochloride, protein, and gender, on live animal performance, carcass cut-ability, quality, belly firmness, and fatty acid composition in swine (Ph.D thesis). University of Georgia, Athens.
StatSoft. (2004). Statistica: data analysis software system: versão 7. Tulsa.

Warriss, P. D. (2010). Meat Science: an introductory text (2nd ed., 384 p.). Wallingford: CABI Publishing.

Wood, J. D., Enser, M., Fisher, A. V., Nute, G. R., Sheard, P. R., Richardson, R. I., Hughes, S. I., \& Whittington, F. M. (2008). Fat deposition, fatty acid composition and meat quality: a review. Meat Science, 78(4), 343-358. PMid:22062452. http://dx.doi.org/10.1016/j. meatsci.2007.07.019. 